\title{
Soil nutrient status and productivity potentials of lithosols in Mubi Area, Northeastern Nigeria
}

\author{
${ }^{1}$ Tekwa, I J*, ${ }^{2}$ Shehu H E and ${ }^{3}$ Maunde S M \\ ${ }^{1}$ Department of Agricultural Technology, Federal Polytechnic, P. M. B 35, Mubi, Nigeria \\ ${ }^{2}$ Department of Crop Science, Adamawa State University, P. M. B 25 Mubi, Nigeria \\ ${ }^{3}$ Dept of Agricultural Technology, Adamawa State College of Agriculture, Ganye, Nigeria \\ ${ }^{*}$ Corresponding Author: johntekwa@gmail.com
}

\begin{abstract}
Continuous and coherent hard rock between 10.0 and $50.0 \mathrm{~cm}$ of topsoil can considerably impede crop production. A field survey was conducted in 2006 to assess the physico-chemical properties, Fa and Pp of lithosols from six locations (Muvur, Digil, Vimtim, Gella, Lamorde, and Madanya) in Mubi area, Northeast Nigeria. Soils were sampled at 0-20, 20-50, and 50-100 cm depths in each of the six locations for the analyses of particle size distribution, bulk density, water holding capacity, $\mathrm{pH}, \mathrm{EC}, \mathrm{OC}, \% \mathrm{~N}$, avail $\mathrm{P}, \mathrm{K}, \mathrm{CEC}, \mathrm{TEB}$ and land qualities including $\mathrm{Fi}$ and $\mathrm{Pi}$ indices. The soils were generally loam textured with low SOM levels, slightly acidic reactions and low soil nutrient amounts. The Fa index for the lithosols rated low (31.80 at Muvur and Vimtim) to good (51.5 at Digil) for rain-fed agriculture and excellent for orchard in all locations. The Pf index was rated good (55.4 at Gella) to excellent (90.50 at Madanya) for rainfed agriculture and excellent for orchard in all locations. The coefficient of improvement (Ci) for fertility index $(\mathrm{Fi})$ for the soils showed that rain-fed agriculture can be improved by 1.54-2.54 times while orchard by 1.11 times only. The Fa index rated extremely low (2.31 at Gella) to moderate (51.12 at Vimtim) for rain-fed agriculture and low (11.25 at Gella) to moderate (58.32 at Madanya) for orchard. Accordingly, the soils can be classified varying from PII(S2) (good or moderate at Vimtim) to PV(N2) (extremely low or not suitable at Gella) for rain-fed agriculture and from PII(S2) (good or moderate at Madanya) to PIV(N 1) (low or presently not suitable at Gella) for orchard. The Pp index was rated low to excellent for rain-fed agriculture and average to excellent for orchard. Accordingly, the soils can be classified as varying from excellent (PI(S 1)) to low (PIV(N1)) for rain-fed agriculture and from excellent (PI(S1)) to average (PIII(S3)) for orchard. The Pp coefficient revealed that rain-fed agriculture can be improved by 2-6 times and orchard by only two-folds. In conclusion, the lithosols studied had medium natural $\mathrm{Fa}$ and $\mathrm{Pp}$ with land slope, poor drainage, stoniness (gravel), and low nutrient levels as limitations. The Fa and $\mathrm{Pp}$ of these lithosols for rain- fed agriculture and orchard can be improved from moderate to high, with appropriate soil fertilization and conservation measures.
\end{abstract}

Keywords: Physico-chemical properties, fertility and productivity potentials, land quality, rainfed agriculture and Lithosols

\section{INTRODUCTION}

The evolving knowledge of the nature and properties of soil has served in better articulation of the potentials and limitations of soils to compatible landuse over the years. A thorough idea on soil pedology and agronomy are therefore important indices in most fertility surveys since soil data provides bases for guiding variety of land applications (Morgan, 1989). Fertility survey data are used in the interpretation of soil fertility status in terms of nutrient reserves, additions, transformations and consequent colossal losses through crop removals, leaching and erosion (Tekwa and Usman, 2006). Studies reveal that the soils of the study area fall under the category of lithosols (Agboola, 1979; Adebayo, 2004; Tekwa and Usman, 2006). Lithosols constitutes one of the upper categories of the FAO/UNESCO soil classification system (Aduayi et al., 2002). They refer to soils with rock-basements within shallow depths from the soil surface and this implies shallowness and stoniness of the surface soil depths, and is usually characterized by orchard-type vegetation due to its limitation in inherent fertility (Nwaka et al., 1999). At the present, no research work has evaluated the soils of Mubi area for its dynamic soil properties and fertility potentials for 
various land uses, however valuable reports on satisfactory statuses of soil productivity in the neighboring areas have been documented (Tekwa and Belel, 2009).

Therefore, the objective of this study was to assess the physical, chemical and fertility potentials of the soils of Mubi area, and to assess the land quality of the study area towards a sustainable agricultural production.

\section{MATERIALS AND METHODS}

Study sites: Mubi area is located in Northeast Nigeria between latitudes $9^{\circ} 26^{\prime}$ and $10^{\circ} 10^{\prime} \mathrm{N}$, and between longitudes $13^{\circ} 1^{\prime}$ and $13^{\circ} 44^{\prime} \mathrm{E}$ (Nwagboso and Uyanga, 1999). The area is characterized by a typical tropical wet (April-October) and dry (November-March) climate with a mean annual rainfall ranging from $700 \mathrm{~mm}$ to $1,050 \mathrm{~mm}$ (Udo, 1970; Adebayo, 2004). The vegetation is a typically sudan savanna type with short grasses interspersed with shrubs and few trees (Adebayo, 2004; Tekwa and Usman, 2006), The land-use type is basically arable farming and animal production. Most prominent physical feature in the area is the Mandara Mountain which spans throughout the length of Mubi area, it has mixed assemblages of scattered granitic outcrops on gentle (0-4\%) to steep (18-22\%) slopes with dissected soil surfaces (Udo, 1970). The geomorphology of the area consists of dissected uplands, pediment slopes and narrow valleys. The six study sites were spread all over the land types. The geology of the area consists of Precambrian basement rocks, while the parent material of the soil is undifferentiated basement complex represented by migmatite-gneisses, schists, quartzites aplite, medium and coarsegrained granites, pegmatite, diorite, and amphibolites (Udo, 1970; Adebayo, 2004).

Site selection and field studies: Six locations (Digil, Muvur, Vimtim, Gella, Lamorde and Madanya) were randomly selected to cover the entire study area using maps and field visits for site documentations. The selected sites were surveyed between April and November, 2004.

The grid system of soil sampling was used to sample soils using spiral auger at $100 \mathrm{~m}$ intervals along transects which were also $100 \mathrm{~m}$ apart within an area of I0 ha. At each site, soil samples were collected from ten points at $0-20,20-50$, and $50-100 \mathrm{~cm}$ depths. The samples were prepared and stored for laboratory analyses. In addition, slope angles were measured with an Abney level. The vegetation density was obtained using a quadrant, while a visual observation was made for present land use types.

Laboratory analyses: The soil samples collected were air-dried and crushed to pass through a $2 \mathrm{~mm}$ sieve, some of the soil samples were further passed through $0.5 \mathrm{~mm}$ sieve for organic matter and total $\mathrm{N}$ determinations. The soils were characterized for their physical and chemical properties following standard laboratory procedures (Klute et al., 1986; Page et al,. 1982). Particle size analysis was determined by Bouyocous hydrometer method while water holding capacity was determined by gravimetric method (Trout et al., 1987). Bulk density was determined by clod method and soil porosity was extrapolated by the computer. Soil reaction $(\mathrm{pH})$ was determined potentiometrically in water using 1 : $2.5 \mathrm{soil} /$ water ratios, while the electrical conductivity (EC) was measured in a soil/water extract using an EC meter (Page et al, 1982). Organic carbon was determined following the procedures of Walkley and Black (1934), from where organic matter was calculated. Total nitrogen $(\mathrm{N})$ was determined by the macro-Kjeldahl method, while available phosphorus (P) was determined by Bray-I method. Available potassium $(\mathrm{K})$ and sodium $(\mathrm{Na})$ were determined by flame photometer. Exchangeable cations and cation exchange capacity (CEC) were determined by the saturated ammonium acetate (1 Normal $\mathrm{NH}_{4} \mathrm{OAc}$ at $\mathrm{pH}$ 7.0) method. Exchangeable acidity (EA) was extracted with 1 Normal $\mathrm{KCl}$ and the percentage base saturation (PBS) was calculated as the sum of the bases (total exchangeable bases, (TEB)) divided by CEC and expressed as percent.

Soil fertility and productivity potentials' evaluation procedure: The fertility potentials of the soils studied were determined from the indices recommended by Sanchez et al. (1982) and calculated using the equation defined by Riquier et al. (1970), modified by Raji (2000) for the evaluation of the productivity of quartzsamments and haplustults derived from contiguous sand dune fields for agriculture, pasture and forestry in Northwest Nigeria. Following the productivity index (Pi) equation given as (Raji, 2000):

$$
\begin{aligned}
& \mathrm{Pa}=\mathrm{H} \times \mathrm{D} \times \mathrm{Dp} \times \mathrm{T} \times \mathrm{Sp} \times \mathrm{Fa} \quad \ldots \ldots \text { Eq. (1) } \\
& \text { Where: } \\
& \mathrm{Pa}=\text { actual productivity (tons/ha) } \\
& \mathrm{H}=\text { soil moisture based on the number of wet } \\
& \text { months } \\
& \mathrm{D}=\text { drainage }\left(\mathrm{mm} / \mathrm{cm}^{3}\right)
\end{aligned}
$$


Dp = effective soil depth (rooting zone to impenetrable layer)

$\mathrm{T}=$ soil texture/structure

$\mathrm{Sp}=$ slope meso-relief of the dunes (\%)

$\mathrm{Fa}=$ actual fertility, consisting of several factors

A separate calculation was done for the fertility index (Fi) using Equation 2 before incorporating $\mathrm{Fa}$, back into Equation 1.

$\mathrm{Fa}=\mathrm{N} \times \mathrm{O} \times \mathrm{C} \times \mathrm{M} \times \mathrm{Ap}$

Where:

$\mathrm{N}=$ soil reaction $(\mathrm{pH})$

$\mathrm{O}=$ organic matter content (\%)

$\mathrm{C}=$ nature of clay taken as CEC per kg clay

$\mathrm{M}=$ mineral reserve

$A p=$ available phosphorus (ppm)

The potential productivity (Pp) index and the potential fertility $(\mathrm{Pf})$ index were then calculated using Equations 1 and 2, respectively. The potential indices were calculated after all envisaged

Table 1: Land productivity and suitability classes and ratings

Land Productivity Classes

Raji (2000); Riquier et al.(1970)

\begin{tabular}{lllll} 
Class & Rate & $\%$ & Class & Rate \\
PI & Excellent & $65-100$ & S1 & High \\
PII & Good & $35-64$ & S2 & Moderate \\
PIII & Average & $20-34$ & S3 & Marginal \\
PIV & Low & $8-19$ & $\mathrm{NI}$ & Presently \\
& & & suitable \\
PV & Extremely low & $0-7$ & N2 & Not suitable \\
\hline
\end{tabular}

The ratings of the limiting soil characteristics and classes remained as defined by Riquier et al (1970).

\section{RESULTS AND DISCUSSION}

Soil physical characteristics: The physical properties of the soils are presented in Table 2. The results showed that the soil of the study area were predominantly loamy textured with high percentage of sand (49-76\%). Muvur and Gella sites had the highest sand content in their pedon, with patched concretions. This property was a reflection of the impeded drainage of the soils, evident between June and August when the rainy season was at its peak (Tekwa and Usman, 2006). Clay content of the soils averaged between 1 and 23\% with Madanya site having the highest and Muvur, the least. According to Nwaka et al (1999), clay accumulation and distribution in the study area show the process of lessivation and illuviation to a certain degree. Generally, soil texture varied from silty loam at Lamorde site, sandy loam at Muvur and Gella sites, to sandy clay loam at Digil, Vimtim and Madanya sites. These textural variations had been attributed to the periodic selective soil deposition and lessivage, occasioned by poor drainage conditions improvements such as conservation measures, liming, fertilization and irrigation. Coefficient of improvement (Ci) which expresses the degree of possible improvement is calculated using Equation 3 (Requier et al., 1970):

$\mathrm{Ci}=\mathrm{Pp} / \mathrm{Pa} \times 100$.

The percentage rating of $\mathrm{Pp}$ and $\mathrm{Pa}$ are then converted to decimal for use in equation 3 and the resulting product, reconverted back into percentages. The soils were grouped into five productivity classes (PI-PV) with FAO (1976) equivalent land suitability classes (S1, S2, S3, N1 and N2) as presented in Table 1.

All data generated were statistically analyzed using the generalized linear model procedure of Statistix 8.0 versions 2004 for ANOVA. Mean values were correlated for various variables. 
slightly strong $(\mathrm{pH} 5.7)$ to strong $(\mathrm{pH} 5.1)$ soil reaction (Table 3 ). The soil pH either decreased (in Madanya and Digil sites) or fluctuated (in Muvur site) with increasing soil depth, probably due to the impeded drainage in these areas. However, the acidic conditions observed are still within tolerable limits for most arable crop production. This observation agrees with earlier reports by Nwaka et al (1999) for similar soils on the Mambilla plateau in the neighboring Taraba state.

Rates of electrical conductivities (EC) for the soils were generally low (0.03- $004 \mathrm{dSm}^{-1}$ ) (Table 3), and implies that the soils are non-saline. Soil organic matter (OM) content was relatively higher at the surface, which decreased with depth and was low to medium in the soils, which is particular to OM depletion pattern with soil depths (Brady and Weil, 2002). It was highest (1.32\%) in the soils at Lamorde site and lowest $(0.33 \%)$ at Madanya site (Table 3 ). The values of organic matter content observed in this study are similar to those reported by Ekwue and Tashiwa (1992) for the same Mubi region.

The total nitrogen $(\mathrm{N})$ content was low, ranging from 0.12 to $0.22 \%$ at between 20 and $100 \mathrm{~cm}$ soil depths. This low value of total nitrogen appears to be a reflection of the low OM content especially in the greater soil depths. The available phosphorus $(\mathrm{P})$ content was moderate to adequate in the lithosols. $\mathrm{P}$ content averaged between $12.08 \mathrm{mg} \mathrm{kg}^{-1}$ (in Madanya) and $34.51 \mathrm{mg} \mathrm{kg}^{-1}$ (in Lamorde). This drastic variation may be attributable to the $\mathrm{OM}$ content which could have resulted from addition of more $\mathrm{P}$ within the topsoil depths. On the other hand, it may be possible that the low soil pH could have contributed to only considerable amounts of available $\mathrm{P}$ due to $\mathrm{P}$-fixation in the soils. Correct dose of nitrogenous and phosphatic fertilizers and organic manures may be necessary at proper application time in order to supplement the soils for optimum crop requirements. Available potassium (K) content of the soils was generally moderate to high in all the lithosols samples studied with mean values of between 0.86 and $9.52 \mathrm{Cmol}(+) \mathrm{kg}^{-1}$ and an overall mean of $2.48 \mathrm{Cmol}^{(+)} \mathrm{kg}^{-1}$ (Table 3). This similar range of available $\mathrm{K}$ was reported by Ekwue and Tashiwa (1992) for the same Mubi soils.

Exchangeable Calcium (Ca) and Magnesium (Mg) appear to increase with depths in most of the sites studied (Table 3). The result reveals that exchangeable Ca varied between $9.02 \mathrm{Cmol}(+) \mathrm{kg}^{-1}$ and $18.57 \mathrm{Cmol}^{(+)} \mathrm{kg}^{-1}$. While $\mathrm{Mg}$ content varied between $3.08 \mathrm{Cmol}^{(+)} \mathrm{kg}^{-1}$ and $11.44 \mathrm{Cmol}(+) \mathrm{kg}^{-1}$.
Both $\mathrm{Ca}$ and $\mathrm{Mg}$ contents were similar in the soils and exhibited greater concentrations at $50-100 \mathrm{~cm}$ depths (Table 3). Gella, Digil and Lamorde comparably had lower amounts of $\mathrm{Ca}$ and $\mathrm{Mg}$, than Muvur, Vimtim and Madanya sites with moderate amounts. In these acidic soils, it is expected that $\mathrm{Ca}$ should be supplied as a nutrient with a high dose of single superphosphate (SSP) fertilizer in order to augment a possible deficiency of $\mathrm{Ca}$ by satisfying a possible P-fixation in the soils. More closely, the $\mathrm{Ca} / \mathrm{Mg}$ ratio observed in this study appears to be generally of either $1: 1$ or 2:1 ratios (Table 3). These ratios indicates the possibility for $\mathrm{Mg}$ deficiency to be seldom, even when its analytical content are low in the soils (Nwaka, et at, 1999). This estimated ratios agrees with the reports of Landon (1991), that Mg will be available to plants, thus the soils may remain fertile over a wide range of Ca:Mg ratios.

Exchangeable Sodium ( $\mathrm{Na}$ ) was generally low in these lithosols, though patchily high $\mathrm{Na}$ concentrations were recorded at soil depths of (1-20 and $20-50 \mathrm{~cm}$ at Larnorde and Digil sites (Table 3). In addition, the soils were generally lower in $\mathrm{Na}$ content at Muvur $\left(0.85 \mathrm{Cmol}(+) \mathrm{kg}^{-1}\right)$ and at Lamorde and Digil which tied at $0.99 \mathrm{Cmol}(+) \mathrm{kg}^{-1}$, indicating that the soils at these sites are still not saline and there is no danger of soil sodicity to cause soil degradation of the soils by secondary salinization due to potential salt build up. However, when irrigation is envisaged, under- and over-irrigation should be avoided, especially in such soils with high soil $\mathrm{pH}$.

Total exchangeable bases (TEB) and the basic cations $\left(\mathrm{Ca}^{2+}, \mathrm{Mg}^{2+}, \mathrm{K}^{+}, \mathrm{N}^{+}\right)$of the soils studied were generally low (Table 3 ). Mean TEB values ranged from $14.79 \mathrm{Cmol}(+) \mathrm{kg}^{-1}$ to $33.44 \mathrm{Cmol}(+) \mathrm{kg}^{-1}$ across the sites and depths studied. Cation Exchange Capacities (CEC) of the soils followed same trend as TEB and averaged between 3.55 $\mathrm{Cmol}(+) \mathrm{kg}^{-1}$ and $7.57 \mathrm{Cmol}(+) \mathrm{kg}^{-1}$ in the lithosols studied, indicating a direct reflection of the observed $\mathrm{Ca}, \mathrm{Mg}$ and O.M contents at the various soil depths. These CEC estimates further suggested a lower rate of clay activity in the soils (Uechara, 1978). Also, Lombin (1981) opined that in soils with low CEC, applications of $\mathrm{Ca}$ and $\mathrm{Mg}$ may be required in addition to K-dressing to maintain the balanced and favorable nutrient ratios.

Soil fertility and productivity potentials: Three environmental factors (climate, topography and soils) are commonly used to assess the potential productivity of land in relation to crops. The amount and distribution of precipitation is an important 
climatic factor which dictates the extent of crop production. Mean annual rainfall estimates in the study area ranged from $700 \mathrm{~mm}$ to $1,050 \mathrm{~mm}$ within seven months (Adebayo, 2004) and this range is considered sufficient for most rain-fed crops such as maize, rice, sorghum, potatoes, cowpea and groundnut, commonly grown in Mubi area (Tekwa and Usman, 2006). The topographic slopes of the study area varied from $0-4 \%$ (flat to moderate slope) to $18-22 \%$ (steep slope). According to Adebayo (2004), soils on $0-4 \%$ slopes is considered safe for economic medium scale farming with minimum risk, while soils on slopes $>7 \%$ should be cultivated with proper conservation measures to avoid erosion, conserve moisture and retain added nutrient. However, some soils on $0-4 \%$ slopes such as those at Digil and Madanya sites have drainage as major limitation to crop production. The suitability of slopes for rain-fed agriculture ranged from highly suitable (on $0-4 \%$ slope) to non-suitable (on $>20 \%$ slope) having main limitations of soil fertility (OM, CEC, total $\mathrm{N}$ and available $\mathrm{P}$ ), soil texture and climate (rainfall). Results show that sites located on flat to gentle slopes had better soil fertility than those on steep slopes due to favorable soil $\mathrm{pH}$, relatively higher organic carbon and P contents. Raji (2000) reported similarly for sand dune soils in Northwestern Nigeria.

The soil reaction was moderate to good, but the OM and exchangeable cation levels in the soils were low, probably due to the effects of land use activities and high temperature which favors rapid mineralization of organic matter (Agboola, 1979). This implies that most of the sites cannot sustain crop production program. However, this fertility limitation can be corrected by applying balanced doses of nitrogenous and phosphatic fertilizers, liming, and the addition of organic matter through effective crop residues management and increased use of leguminous plants such as soybean in crop rotations (Shehu et al 2007). In addition, terracing and contour cultivation can be used on moderate to steep slopes (10-22\%) to reduce runoff, control soil erosion and reduce soil fertility loss.

The results for the evaluation of the soils for its $\mathrm{Fa}$ and $\mathrm{Pp}$ with respect to rain-fed agriculture and orchard are presented in Table 3. Fa index for the rain fed agriculture ranged from a low value of 31.80 (in Muvur and Vimtim locations) to good (51.50) at Digil location, while the rating for orchard was excellent (90.00) in all the locations. The Pf index for the rain-fed agriculture ranged from good (55.40) at
Gella to excellent (90.50) at Madanya location. However, the soil Pf index for orchard was excellent (100.00) in all locations. After improvements in soil fertilization, liming, organic manure application to the soils, and contour cultivation, the soil Pf index of rain-fed agriculture increased by 1.54 times at Gella to 2.54 times at Muvur location. However, orchard can only be improved by 1.11 time in all locations studied.

The soil $\mathrm{Pa}$ index for the rain-fed agriculture ranged from an extremely low value of 2.31 at Gella location to good value (51.12) at Vimtim. The value of $\mathrm{Pa}$ for orchard ranged from a low value (11.25) at Gella to good (58.32) at Madanya location. The results show that $\mathrm{Pa}$ index for both rain-fed agriculture and orchard ranged from extremely low to good, implying that $\mathrm{Pa}$ was low to moderate. The soil $\mathrm{Pp}$ index for rain-fed agriculture ranged from a low value (8.50) at Gella to excellent (80.50) at Madanya location. However, the rating for orchard ranged from an average value of 21.60 at Gella to an excellent value of 80.50 at Madanya location. This result implies that after improving the soil conditions, the soil $\mathrm{Pp}$ index for the rain-fed agriculture can range from low to excellent on these lithosols.

Based on Raji (2000); Riquier et al. (1970) and FAO (1976), the $\mathrm{Pa}$ class for the rain-fed agriculture ranged from good (PII) or moderate (S2) at Vimtim location to extremely low (PV) or not suitable (N2) at Gella. However, the values for orchard ranged from (PII or S2) at Madanya to PIV or NI at Gella. The results imply that $\mathrm{Pa}$ class for rain-fed agriculture was good or moderately suitable at Vimtim location but not suitable at Gella with the other locations falling between these $\mathrm{Pa}$ classes.

The soil $P p$ index for rain-fed agriculture ranged from excellent (PI or S1)) at Vimtim to low (PIV or N1) at Gella while for orchard, it ranged from excellent (PI or S1) at Madanya to average (PIII or S3) at Gella. These imply that the Pp for rain-fed agriculture will encounter fewer limitations at Vimtim than Gella, while without any limitations for orchard establishment at Madanya. After ameliorating the land of its limitations, the soil productivity coefficient (PC) for the rain-fed agriculture ranged from 1.52 (Vimtim location) to 5.85 times at Lamorde; while the soil PC for orchard ranged from 1.29 at Digit to 2.29 times at Lamorde. This result imply that the Pp for rain-fed agriculture can be increased by about 2 to 6 times, while that for the orchard by from one to twofolds

only 
Table 2: Physical land qualities/characteristics of Lithosols in Mubi area, Northeast Nigeria

\begin{tabular}{|c|c|c|c|c|c|c|c|c|c|c|c|c|c|c|}
\hline \multirow[t]{2}{*}{ Location } & \multicolumn{2}{|c|}{ Annual Rainfall } & \multirow{2}{*}{$\begin{array}{l}\text { Slope } \\
\text { ranges } \\
(\%)\end{array}$} & \multirow{2}{*}{$\begin{array}{l}\text { Drainage } \\
\text { condition }\end{array}$} & \multirow[t]{2}{*}{ Depth } & \multirow{2}{*}{$\begin{array}{l}\text { Gravel } \\
(\%)\end{array}$} & \multicolumn{3}{|c|}{ Particle Size Distribution } & \multirow{2}{*}{$\begin{array}{l}\text { Textural } \\
\text { Class }\end{array}$} & \multirow{2}{*}{$\begin{array}{l}\text { Bulk } \\
\text { Density } \\
\left(\mathrm{Mgm}^{-1}\right)\end{array}$} & \multirow{2}{*}{$\begin{array}{l}\text { Total } \\
\text { Porosity } \\
\text { (\%) }\end{array}$} & \multirow{2}{*}{$\begin{array}{l}\text { Water } \\
\text { Holding } \\
\text { Capacity } \\
(\%)\end{array}$} & \multirow{2}{*}{$\begin{array}{l}\text { Aggregate } \\
\text { Stability } \\
\text { MWD } \\
(\mathrm{mm})\end{array}$} \\
\hline & $\begin{array}{l}\text { Amount } \\
(\mathrm{mm})\end{array}$ & Months & & & & & $\begin{array}{l}\text { Sand } \\
(\%)\end{array}$ & $\begin{array}{l}\text { Silt } \\
(\%)\end{array}$ & $\begin{array}{l}\text { Clay } \\
(\%)\end{array}$ & & & & & \\
\hline \multirow[t]{4}{*}{ Digil } & $700-1050$ & 5 & $0-4$ & Well & $0-20$ & 3.0 & 54.95 & 17.50 & 32.55 & SCL & 1.51 & 38.24 & 29.10 & 1.42 \\
\hline & & & & & $20-50$ & 12.0 & 56.20 & 13.20 & 31.60 & SCL & 1.44 & 42.34 & 27.70 & 1.59 \\
\hline & & & & & $50-100$ & 8.0 & 78.50 & 01.20 & 11.30 & LS & 1.43 & 45.80 & 24.20 & 1.61 \\
\hline & & & & & Mean & 8.3 & 63.22 & 13.63 & 25.15 & & 1.46 & 42.13 & 27.00 & 1.54 \\
\hline \multirow[t]{4}{*}{ Muvur } & $700-1050$ & 5 & $6-8$ & Well & $0-20$ & 6.1 & 78.40 & 02.50 & 19.50 & LS & 1.31 & 48.43 & 23.10 & 1.40 \\
\hline & & & & & $20-50$ & 17.2 & 77.90 & 05.00 & 17.50 & LS & 1.18 & 53.91 & 19.87 & 1.55 \\
\hline & & & & & $50-100$ & 13.1 & 70.50 & 12.00 & 17.50 & SL & 1.02 & 61.74 & 19.33 & 1.58 \\
\hline & & & & & Mean & 12.0 & 75.60 & 06.50 & 18.17 & & 1.17 & 54.69 & 20.77 & 1.51 \\
\hline \multirow[t]{4}{*}{ Vimtim } & $700-1050$ & 5 & $7-8$ & Well & $0-20$ & 7.1 & 48.50 & 22.40 & 29.10 & $C L$ & 1.45 & 42.46 & 14.35 & 1.34 \\
\hline & & & & & $20-50$ & 19.1 & 47.40 & 22.40 & 30.20 & SCL & 1.18 & 53.91 & 21.85 & 1.50 \\
\hline & & & & & $50-100$ & 14.2 & 50.35 & 22.40 & 27.25 & SCL & 1.34 & 50.00 & 29.12 & 1.47 \\
\hline & & & & & Mean & 13.3 & 48.75 & 22.40 & 28.85 & & 1.32 & 48.79 & 21.77 & 1.44 \\
\hline \multirow[t]{4}{*}{ Gella } & $700-1050$ & 5 & $20-22$ & Very well & $0-20$ & 10.1 & 70.80 & 12.20 & 17.00 & SL & 1.33 & 48.48 & 20.90 & 1.23 \\
\hline & & & & & $20-50$ & 29.2 & 70.35 & 12.50 & 17.15 & SL & 1.29 & 50.78 & 19.82 & 1.51 \\
\hline & & & & & $50-100$ & 10.1 & 62.35 & 02.50 & 35.15 & SCL & 1.32 & 49.03 & 19.50 & 1.47 \\
\hline & & & & & Mean & 16.3 & 67.83 & 09.07 & 23.10 & & 1.31 & 49.42 & 20.07 & 1.40 \\
\hline \multirow[t]{4}{*}{ Lamorde } & $700-1050$ & 5 & $7-10$ & Well & $0-20$ & 6.1 & 64.50 & 15.50 & 20.20 & SL & 1.23 & 50.99 & 26.54 & 1.32 \\
\hline & & & & & $20-50$ & 20.2 & 63.85 & 15.90 & 20.05 & SL & 1.31 & 49.27 & 25.20 & 1.49 \\
\hline & & & & & $50-100$ & 11.1 & 68.20 & 14.30 & 17.50 & SL & 1.15 & 56.27 & 20.84 & 1.50 \\
\hline & & & & & Mean & 12.4 & 65.52 & 15.23 & 19.25 & & 1.23 & 52.23 & 24.19 & 1.44 \\
\hline \multirow[t]{4}{*}{ Madanya } & $700-1050$ & 5 & $0-4$ & Very well & $0-20$ & 2.2 & 58.65 & 17.40 & 23.95 & SCL & 1.43 & 45.80 & 22.22 & 1.43 \\
\hline & & & & & $20-50$ & 11.2 & 57.60 & 05.50 & 36.90 & SCL & 1.32 & 50.38 & 30.58 & 1.58 \\
\hline & & & & & 50-100 & 7.2 & 58.80 & 05.50 & 37.70 & SCL & 1.55 & 47.90 & 29.00 & 1.59 \\
\hline & & & & & Mean & 6.9 & 58.35 & 09.47 & 32.85 & & 1.43 & 46.36 & 27.27 & 1.53 \\
\hline
\end{tabular}


Table 3: Chemical characteristics of Lithosols in Mubi area, Northeast Nigeria

\begin{tabular}{|c|c|c|c|c|c|c|c|c|c|c|c|c|c|}
\hline \multirow{2}{*}{$\begin{array}{l}\text { Location } \\
\text { Digil }\end{array}$} & \multirow{2}{*}{$\begin{array}{l}\begin{array}{l}\text { Depth } \\
\text { (cm) }\end{array} \\
0-20\end{array}$} & \multirow{2}{*}{$\begin{array}{l}\mathrm{pH} \\
(1: 2.5 \\
\text { soil:water) } \\
5.57\end{array}$} & \multirow{2}{*}{$\begin{array}{l}\begin{array}{l}\mathrm{EC} \\
\left(\mathrm{dSm}^{-1}\right)\end{array} \\
0.03\end{array}$} & \multirow{2}{*}{$\begin{array}{l}\mathrm{OM} \\
(\%)\end{array}$} & \multirow{2}{*}{$\begin{array}{l}\mathrm{N} \\
(\%)\end{array}$} & \multirow{2}{*}{$\begin{array}{l}\mathrm{P} \\
\left(\mathrm{mg} \mathrm{kg}^{-1}\right)\end{array}$} & \multicolumn{2}{|c|}{$\begin{array}{l}\mathrm{K} \quad \mathrm{Ca} \\
\left(\mathrm{Cn} b l(+) \mathrm{kg}^{-1}\right)\end{array}$} & \multirow{2}{*}{$\begin{array}{l}\mathrm{Mg} \\
2.21\end{array}$} & \multirow{2}{*}{$\begin{array}{l}\text { TEB } \\
15.45\end{array}$} & \multirow{2}{*}{$\begin{array}{r}\text { EA } \\
- \\
1.0\end{array}$} & \multirow{2}{*}{$\begin{array}{r}\text { CEC } \\
3.51\end{array}$} & \multirow{2}{*}{ } \\
\hline & & & & & & & 3.29 & 9.02 & & & & & \\
\hline & $20-50$ & 5.53 & 0.04 & 0.67 & 0.16 & 14.12 & 2.41 & 9.21 & 2.51 & 15.23 & 1.0 & 3.37 & 71.59 \\
\hline & $50-100$ & 5.17 & 0.02 & 0.66 & 0.15 & 8.45 & 3.52 & 14.54 & 6.12 & 25.14 & 0.5 & 5.98 & 80.24 \\
\hline & Mean & 5.42 & 0.03 & 0.67 & 0.15 & 13.26 & 3.07 & 10.92 & 3.61 & 18.61 & 0.8 & 4.29 & 74.70 \\
\hline \multirow[t]{4}{*}{ Muvur } & $0-20$ & 5.52 & 0.03 & 1.18 & 0.17 & 38.81 & 2.84 & 11.02 & 2.15 & 16.81 & 0.5 & 4.81 & 82.23 \\
\hline & $20-50$ & 5.34 & 0.02 & 0.21 & 0.18 & 16.85 & 1.12 & 10.21 & 6.21 & 18.44 & 0.5 & 5.12 & 81.23 \\
\hline & $50-100$ & 5.55 & 0.02 & 0.14 & 0.08 & 17.12 & 0.98 & 17.41 & 8.56 & 27.74 & 0.1 & 7.71 & 83.11 \\
\hline & Mean & 5.47 & 0.02 & 0.51 & 0.14 & 24.26 & 1.65 & 12.88 & 5.64 & 20.99 & 0.7 & 5.88 & 82.19 \\
\hline \multirow[t]{4}{*}{ Vimtim } & $0-20$ & 5.12 & 0.03 & 1.88 & 0.21 & 30.22 & 2.21 & 6.95 & 4.31 & 14.38 & 1.0 & 4.64 & 75.98 \\
\hline & $20-50$ & 5.11 & 0.03 & 0.68 & 0.14 & 27.45 & 1.65 & 9.85 & 4.15 & 16.43 & 1.0 & 4.68 & 73.56 \\
\hline & $50-100$ & 5.91 & 0.02 & 0.59 & 0.14 & 16.01 & 1.83 & 12.91 & 7.41 & 23.14 & 1.0 & 7.36 & 74.11 \\
\hline & Mean & 5.38 & 0.03 & 1.05 & 0.16 & 24.56 & 1.90 & 9.90 & 5.29 & 17.98 & 1.0 & 5.56 & 74.55 \\
\hline \multirow[t]{4}{*}{ Gella } & $0-20$ & 5.09 & 0.06 & 0.55 & 0.11 & 45.12 & 3.55 & 8.45 & 3.01 & 15.89 & 0.2 & 3.78 & 76.33 \\
\hline & $20-50$ & 5.31 & 0.04 & 0.35 & 0.14 & 35.01 & 1.29 & 8.95 & 3.02 & 14.09 & 0.1 & 3.44 & 76.49 \\
\hline & $50-100$ & 5.58 & 0.04 & 0.29 & 0.16 & 20.51 & 0.86 & 9.65 & 3.21 & 14.40 & 1.0 & 3.44 & 76.78 \\
\hline & Mean & 5.33 & 0.05 & 0.40 & 0.14 & 33.55 & 1.90 & 9.02 & 3.08 & 14.79 & 0.5 & 3.55 & 76.53 \\
\hline \multirow[t]{4}{*}{ Lamorde } & $0-20$ & 5.23 & 0.03 & 1.90 & 0.17 & 41.75 & 9.52 & 8.02 & 0.51 & 19.27 & 0.2 & 4.76 & 76.13 \\
\hline & $20-50$ & 5.24 & 0.02 & 1.55 & 0.15 & 38.15 & 1.43 & 9.81 & 7.21 & 19.31 & 0.3 & 4.88 & 76.85 \\
\hline & $50-100$ & 5.32 & 0.04 & 0.50 & 0.12 & 23.63 & 1.03 & 10.15 & 8.21 & 20.24 & 0.1 & 4.94 & 77.01 \\
\hline & Mean & 5.26 & 0.03 & 1.32 & 0.15 & 34.51 & 3.99 & 9.33 & 5.31 & 19.61 & 0.2 & 4.86 & 76.66 \\
\hline \multirow[t]{4}{*}{ Madanya } & $0-20$ & 5.96 & 0.04 & 0.61 & 0.18 & 12.81 & 2.23 & 19.44 & 9.01 & 31.59 & 1.0 & 7.61 & 72.53 \\
\hline & $20-50$ & 5.39 & 0.02 & 0.23 & 0.15 & 13.53 & 2.51 & 17.31 & 12.15 & 33.31 & 1.0 & 8.03 & 72.97 \\
\hline & $50-100$ & 5.52 & 0.02 & 0.14 & 0.12 & 9.91 & 2.32 & 18.95 & 13.15 & 35.41 & 1.0 & 7.08 & 73.12 \\
\hline & Mean & 5.62 & 0.03 & 0.33 & 0.15 & 12.08 & 2.35 & 18.57 & 11.44 & 33.44 & 1.0 & 7.57 & 72.87 \\
\hline \multicolumn{2}{|c|}{ Grand mean } & 5.41 & 0.03 & 0.17 & 0.15 & 23.70 & 2.48 & 11.77 & 5.29 & 20.90 & 0.7 & 5.29 & 76.26 \\
\hline
\end{tabular}


Table 4: Percentage ratings of individual factors of soil fertility and land productivity indices for Lithosols in Mubi area, Northeast Nigeria.

\begin{tabular}{|c|c|c|c|c|c|c|c|c|c|c|c|c|c|c|c|c|c|c|c|}
\hline \multirow[t]{2}{*}{ Location } & \multirow{2}{*}{$\begin{array}{l}\text { Land } \\
\text { Use }\end{array}$} & \multirow{2}{*}{$\begin{array}{l}\text { Soil } \\
\text { moisture }\end{array}$} & \multirow{2}{*}{$\begin{array}{l}\text { Drainage } \\
\text { Condition }\end{array}$} & \multirow{2}{*}{$\begin{array}{l}\text { Soil } \\
\text { Depth }\end{array}$} & \multirow[t]{2}{*}{ Texture } & \multirow{2}{*}{$\begin{array}{l}\text { Meso } \\
\text { relief/ } \\
\text { Slope }\end{array}$} & \multirow[t]{2}{*}{$\mathrm{pH}$} & \multirow{2}{*}{$\begin{array}{l}\text { Nature } \\
\text { of clay }\end{array}$} & \multirow{2}{*}{$\begin{array}{l}\text { Soil } \\
\text { mineral } \\
\text { reserve }\end{array}$} & \multirow{2}{*}{$\begin{array}{l}\text { Avail. } \\
\text { Ph. }\end{array}$} & \multirow[t]{2}{*}{ O.M } & \multicolumn{3}{|c|}{ Soil fertility index } & \multicolumn{5}{|c|}{ Soil productivity index } \\
\hline & & & & & & & & & & & & $A$ & $\mathrm{P}$ & $\mathrm{C}_{2}$ & $A$ & $C$ & $\mathrm{P}$ & C & $\mathrm{C}_{1}$ \\
\hline \multirow[t]{2}{*}{ Digil } & $\begin{array}{l}\text { Rainfed } \\
\text { Agric. }\end{array}$ & 80 & 80 & 60 & 100 & 100 & 100 & \multirow[t]{2}{*}{95} & \multirow[t]{2}{*}{85} & 90 & \multirow[t]{2}{*}{75} & 54.51 & 85.90 & 1.56 & 20.93 & $\begin{array}{l}\text { PIII } \\
\text { (S3) }\end{array}$ & 42.10 & $\begin{array}{l}\text { PII } \\
\text { (S2) }\end{array}$ & 2.01 \\
\hline & Orchard & 100 & 90 & 70 & 100 & 100 & 95 & & & 95 & & 90.25 & 100.0 & 1.01 & 58.25 & $\begin{array}{l}\text { PII } \\
\text { (S2) }\end{array}$ & 75.30 & $\begin{array}{l}\mathrm{PI} \\
\text { (S1) }\end{array}$ & 1.29 \\
\hline \multirow[t]{2}{*}{ Muvur } & $\begin{array}{l}\text { Rainfed } \\
\text { Agric. }\end{array}$ & 60 & 90 & 60 & 100 & 90 & 75 & \multirow[t]{2}{*}{95} & \multirow[t]{2}{*}{85} & 70 & \multirow[t]{2}{*}{75} & 31.80 & 80.93 & 2.54 & 9.27 & $\begin{array}{l}\text { PIV } \\
\text { (N1) }\end{array}$ & 39.50 & $\begin{array}{l}\text { PII } \\
\text { (S2) }\end{array}$ & 4.26 \\
\hline & Orchard & 75 & 100 & 70 & 100 & 100 & 95 & & & 90 & & 90.00 & 100.0 & 1.01 & 47.25 & $\begin{array}{l}\text { PII } \\
\text { (S2) }\end{array}$ & 65.40 & $\begin{array}{l}\mathrm{PI} \\
\text { (S1) }\end{array}$ & 1.38 \\
\hline \multirow[t]{2}{*}{ Vimtim } & $\begin{array}{l}\text { Rainfed } \\
\text { Agric. }\end{array}$ & 60 & 90 & 50 & 100 & 60 & 75 & \multirow[t]{2}{*}{95} & \multirow[t]{2}{*}{85} & 70 & \multirow[t]{2}{*}{75} & 31.80 & 75.26 & 2.37 & 51.52 & $\begin{array}{l}\text { PII } \\
\text { (S2) }\end{array}$ & 78.50 & $\begin{array}{l}\mathrm{PI} \\
\text { (S1) }\end{array}$ & 1.52 \\
\hline & Orchard & 80 & 100 & 60 & 100 & 70 & 95 & & & 90 & & 90.00 & 100.0 & 1.01 & 30.24 & $\begin{array}{l}\text { PIII } \\
\text { (S3) }\end{array}$ & 50.60 & $\begin{array}{l}\text { PII } \\
\text { (S2) }\end{array}$ & 1.67 \\
\hline \multirow[t]{2}{*}{ Gella } & $\begin{array}{l}\text { Rainfed } \\
\text { Agric. }\end{array}$ & 40 & 100 & 40 & 100 & 40 & 75 & \multirow[t]{2}{*}{95} & \multirow[t]{2}{*}{85} & 70 & \multirow[t]{2}{*}{75} & 36.03 & 55.41 & 1.54 & 2.31 & $\begin{array}{l}\text { PV } \\
\text { (N2) }\end{array}$ & 8.50 & $\begin{array}{l}\text { PIV } \\
\text { (N1) }\end{array}$ & 3.67 \\
\hline & Orchard & 50 & 100 & 50 & 100 & 50 & 100 & & & 90 & & 90.00 & 100 & 1.01 & 11.25 & $\begin{array}{l}\text { PIV' } \\
\text { (N1) }\end{array}$ & 21.60 & $\begin{array}{l}\text { PIII } \\
\text { (S3) }\end{array}$ & 1.92 \\
\hline \multirow[t]{2}{*}{ Lamorde } & $\begin{array}{l}\text { Rainfed } \\
\text { Agric. }\end{array}$ & 60 & 40 & 50 & 100 & 60 & 75 & \multirow[t]{2}{*}{95} & 85 & 70 & 75 & 42.39 & 70.62 & 1.67 & 3.05 & $\begin{array}{l}\text { PV } \\
\text { (N2) }\end{array}$ & 17.90 & $\begin{array}{l}\text { PIV } \\
\text { (N1) }\end{array}$ & 5.85 \\
\hline & Orchard & 80 & 50 & 60 & 100 & 80 & 75 & & & 90 & & 90.00 & 100 & 1.01 & 17.28 & $\begin{array}{l}\text { PIV' } \\
\text { (N1) }\end{array}$ & 39.40 & $\begin{array}{l}\text { PII } \\
\text { (S2) }\end{array}$ & 2.28 \\
\hline Madanya & $\begin{array}{l}\text { Rainfed } \\
\text { Agric. }\end{array}$ & 80 & 80 & 60 & 100 & 90 & 80 & 95 & 85 & 70 & 75 & 48.45 & 90.50 & 1.87 & 16.76 & $\begin{array}{l}\text { PIV } \\
\text { (N1) }\end{array}$ & 32.80 & $\begin{array}{l}\text { PIII } \\
\text { (S3) }\end{array}$ & 1.96 \\
\hline & Orchard & 100 & 100 & 90 & 100 & 100 & 100 & & & 95 & & 90.00 & 100 & 1.01 & 58.32 & $\begin{array}{l}\text { PII } \\
\text { (S2) }\end{array}$ & 80.50 & $\begin{array}{l}\mathrm{PI} \\
\text { (S1) }\end{array}$ & 1.38 \\
\hline
\end{tabular}

Key: PI= excellent (65-100\%), PII= good (35-64\%), PIII= average (20-34\%), PIV= low (8-19\%), PV= extremely low (0-7\%), S1= high, S2= moderate

$\mathrm{S} 3=$ marginal, N1= presently not suitable, N2 = not suitable, $\mathrm{Ci}=$ coefficient of improvement; $\mathrm{A}=$ actual; $\mathrm{P}=$ potential; OM $=$ organic matter; Ph. Phosphorus

Udo R K., 1970. Geographical Regions of Nigeria, ${ }^{\text {st }}$ Edn. Heinemann. London. 


\section{CONCLUSION}

1. The soil properties (Tables 2 and 3) depict the soils (lithosols) was generally low in nitrogen, phosphorus and high in potassium contents (Landon, 1991). Though the OM, CEC and TEB were generally low, yet, these soils could be considered as having a high fertility status with promising crop production potentials. However, the occasionally poor drainages, compactness, surface stoniness and shallow soil depths characteristic of lithosols, only constitutes a mild degree of limitations. This opines equally with SFCC system (Sanchez, et al, 1982) that these soils displayed only few limitations.

2. The lithosols in the study area (Table 3) could therefore be categorized as PII, PIII, and PV according to Raji (2000) and Riquier et al (1970); or S2, S3-s and S3-d, N1 and N2 according to FAO (1976) and Sanchez et al. (1982), as the case applies. The results imply that the lithosols studied were between good to marginally suitable with slope, stoniness, shallowness, and drainage as much as soil nutrients as limitations. This may be why these soils are continually being cultivated without a significant drop in crop returns (Landon, 1991). In addition, rating for land $\mathrm{Fi}$ and $\mathrm{Pi}$ indices for rain-fed agriculture and orchard, showed that soils on flat and gently sloping topography were excellent (P1 or SI) to moderately suitable (S2 or PII), while, the soils on the steep slopes were marginally suitable (S3 or PIII) to not suitable (PV and N2). The coefficient of improvement $(\mathrm{Ci})$, calculated for rain-fed agriculture and orchard tops show that both fertility and productivity indices of the land can have their suitability classes improved by 1.11 to 2.54 times for fertility index and by 1.29 to 5.85 times for productivity index) (Table 3 ).

3. From the foregoing, the fertility (31-90\%) and productivity (2-58\%) indices ratings of the lithosols in Mubi area were generally adequate for rain-fed agriculture and orchard as shown in Table 3 . In addition, the soil fertility can be improved to between 55 and $100 \%$ and the productivity potential of the soils to between 21 and $81 \%$ (Table 3). These improvements in the fertility and productivity potentials of the land imply an opportunity for the soils to potentially support such crops as rice, wheat, sugar-cane, onion and cabbage for Digil and Madanya locations; guinea-corn, maize, millet, beniseed and cowpea for Muvur, Vimtim, Gella and Lamorde locations; and orchards in all locations especially on the numerously patched 'fadama' grounds with high Pf.

\section{REFERENCES}

Adebayo AA., 2004. Mubi Region: A geographical synthesis (Ist Eds). Paraclete Publishers, Yola-Nigeria. Pp 32-38.

Aduayi, EA, VO Chude, BA Adebusuyi and SO Olayiwola., 2002. Fertilizer use and Management Practices for Crops in Nigeria $\left(3^{\text {rd }}\right.$ Ed.), Federal Fertilizer Department, Federal Ministry of Agriculture and Rural Development, Abuja, Nigeria, Garko International Limited.

Agboola, SA., 1979. An Agricultural Atlas of Nigeria Agriculture, Land Use and Regions. Oxford University press, Pp 195-206.

Brady, N.C. and R.R Weil., 2002. The nature and properties of soils ( $13^{\text {th }}$ edition) Pearson Educ. Pub, New Delhi: India.

Ekwue El and YI Tashiwa., 1992. Survey of gully erosion features in Mubi L.G.A of Adamawa State. Annals of Borno 8/9:181-191.

FAO., 1976. A framework for land evaluation, FAO Soil Bulletin No. 32, FAO, Rome .Pp 72

Klute A., 1986. Methods of soil analysis, Part 1, Agronomy No. 9, American Society of Agronomy, Madison, Wisconsin, USA.

Landon JM., 1991. Booker Tropical Soil Manual, Longman.

Lombin G., 1981. The effects of continuous fertilization on nutrient balance and crop yield in the Northern Nigeria. Canadian Journal of Soil Science. 6:55-65.

Morgan RPC., 1989. Soil Erosion and Conservation. John Wiley and Sons mc: pp8-30.

Nwaboso NK and J Uyanga., 1999. Population. In: AA Adebayo and AL Tukur (Eds) Adamawa State in Maps. Department Geography, F.U.T. Yola Pp.92.

Nwaka G1C, AB Alhassan and AM Kunduri., 1999. A study of soils derived from Basalt in North Eastern, Nigeria 11. Physico-chemical characteristics and fertility status. Journal of Arid Agriculture. 9:89-98, Maiduguri, Nigeria.

Page AL, RH Miller and DR Keeney., 1982. Methods of soil Analysis, part 2, Agronomy No. 9, American Society of Agronomy, Madison, Wisconsin, USA.

Raji BA., 2000. Productivity evaluation of quartzipsamments and haplustults derived from contiguous sand dune fields for rain fed agriculture, pasture and forestry in Northwest Nigeria. Soil Science Society of Nigeria proceedings, 26th annual conference of the Soil Science Society of Nigeria (SSSN), at Ibadan, Oct. 30-Nov. 3, 2000. Pp I2-18. 
Agric. Biol. J. N. Am., 2011, 2(6): 887-896

Riquier S, DL Bramao and IP Cornet., 1970. A new system of soil appraisal in terms of actual and potential productivity. FAO, Rome, 44pp.

Sanchez PA, W Cuto and SW Boul., 1982. The fertility capability soil classification system (SFCC) Interpretation, applicability and modification. Geoderrna. 27:283-309.

Shehu HE, JD Kwari and PM Bzugu., 2007. An exploratory survey of soybean production as influenced by soil fertility status of soils in Mubi, North-eastern Nigeria. Journal of Agronomy 6(4): 576-580
Tekwa IJ and BH Usman., 2006. Estimation of soil loss by gully erosion in Mubi Adamawa State, Nigeria. Journal of the Environment, 1:35-43

Tekwa IJ and MD Belel., 2009. Impacts of traditional soil conservation practices on sustainable food production. Journal of Agriculture and Social Sciences. 5: 128-130. Faisalabad-Pakistan.

Trout, T.J., Garcia-Castilas, I.G. and Hyart, W.E., 1987. Soil water engineering, field and laboratory manual. M/S Eurasia. New Delhi. India. 